DOI 10.32900/2312-8402-2020-123-39-48

УДК 636.1.083.38:591.1

\title{
EXERCISE-INDUCED ALTERATIONS OF THE OXIDATIVE STRESS BIOMARKERS IN ERYTHROCYTESOF PONIES INVOLVED IN RECREATIONAL HORSEBACK RIDING
}

\author{
Tkachenko H., Doctor of Biological Sciences \\ Kurhaluk N., Doctor of Biological Sciences \\ Institute of Biology and Earth Sciences, Pomeranian University in Słupsk, Poland \\ Tkachova I., Doctor of Agrarian Sciences \\ The Institute of Animal Science NAAS, Kharkiv, Ukraine
}

\begin{abstract}
The aim of the current study was the analysis of the oxidative stress biomarkers, as well as the osmotic-induced resistance of erythrocytes in mares and stallions of ponies involved in recreational horseback riding in Pomeranian regions. Ten healthy adult Hucul ponies (5 stallions and 5 mares), 5-11 years old, from Pomeranian regions in Poland (Ustka city, Pomeranian Voivodship, Poland) were used in our study. All horses participated in recreational horseback riding and were subjected to the resembling type of management. The training was continued 1 hour and included a ride of cross country by walking (10 min), trotting (15 min), walking (10 min), galloping (15 min), and walking (10 min). Blood was drawn from jugular veins of the animals in the morning, 90 minutes after feeding, and immediately after the exercise session. Marker of lipid peroxidation (2-Thiobarbituric acid reactive substances, TBARS), aldehydic and ketonic derivatives in the erythrocytes, total antioxidant capacity (TAC) level in the erythrocytes of both mares and stallions exhibited non-significant changes immediately after exercise as compared to the resting period. Both at the rest and after the training session, the levels of TBARS, aldehydic and ketonic derivatives in the erythrocyte suspensions of mares were non-significantly higher compared to stallions. In a like manner, differences of aldehydic and ketonic derivatives of oxidatively modified proteins between mares and stallions after training sessions were noted. Both at the rest and after the training session, the TAC level in the erythrocyte suspensions of stallions was non-significantly higher compared to mares. Among both mares and stallions, a nonsignificantly decreased erythrocyte hemolysis was observed after training sessions compared to the rest period. A comparison of erythrocyte hemolysis in mares and stallions at the rest period showed increased values of hemolysis in the stallions. After the training session, decreased hemolysis was observed in the stallions compared to mares. Efforts should be directed toward a thorough characterization of antioxidant defenses, as well as the correlation links between oxidative stress biomarkers and antioxidant defenses including age- and gender-related differences in the training programs of horses involved in the recreational horseback ridings.
\end{abstract}

Keywords: 2-Thiobarbituric acid reactive substances, aldehydic and ketonic derivatives, oxidatively modified proteins, total antioxidant capacity, erythrocyte hemolysis, training program

Exercise has been shown to increase the production of reactive oxygen species (ROS) to the point that it can exceed antioxidant defenses to cause oxidative stress [20]. Oxidants are essentially generated by metabolic enzymes, inflammatory cells, and mitochondrial electron leakage; they are indispensable for the cellular redox regulation and may, under certain conditions, have a pro-inflammatory stimulatory role [11]. High levels of oxidants and their by-products can compromise the athletic ability of a horse and 
may lead to chronic diseases, i.e. fatigue, muscle damage, and reduced immune function, which can all affect exercise performance [7, 9-11]. Thus, there is a paradox between acute exercise, increasing oxidative stress, and regular exercise having beneficial effects on health and exercise performance [16-17]. However, exercise-induced oxidative stress and increased ROS generation may induce membrane lipid peroxidation and protein damage of erythrocytes and thereby decrease their membrane integrity [6].

Erythrocytes appear much more vulnerable to oxidative damage during intense exercise because of their continuous exposure to high oxygen fluxes and their high concentrations of polyunsaturated fatty acids and heme iron [14]. The major generators of reactive species located in blood during exercise could be erythrocytes (mainly due to their quantity) and leukocytes (mainly due to their drastic activation during exercise) [13]. In our previous studies, different responses of hematological parameters, oxidative stress biomarkers, as well as antioxidant defenses in the blood of welltrained horses and horses involved in the recreational horseback ridings were demonstrated $[1-4,18]$. Recent studies of equine exercise physiology have focused mainly on the evaluation of particular parameters (hematological and biochemical) and changes in their reference ranges depend on the type of exercise [15].

The physical effort and training-induced stress in horses differ depending on equine sporting discipline, as well as on horse breeds. The proper training program aims to adapt a horse's organism to the physiological changes occurring during intense physical effort $[8,15]$. Necessary adaptive mechanisms are formed during that training cycle, giving the possibility of reaching a high level of efficiency with a concurrent decrease in the risk of injuries [8]. The adaptive changes include an increase in heart stroke volume and as a consequence an increase in oxygen utilization in muscles [15]. The cardiovascular system is exposed to modifications essential to ensure efficient transfer of oxygen and substrates to the muscles and allowing removal of metabolites from them. Information concerning physical effort is thus essential in making suitable decisions about proper training strategy.

Thus, the aim of the current study was the analysis of the oxidative stress biomarkers, as well as the urea-induced resistance of erythrocytes in mares and stallions of ponies involved in recreational horseback riding in Pomeranian regions.

Materials and methods. Horses. Ten healthy adult Hucul ponies (5 stallions and 5 mares), 5-11 years old, from Pomeranian regions in Poland (Ustka city, $54^{\circ} 34^{\prime} 43^{\prime \prime} \mathrm{N} 16^{\circ} 52^{\prime} 09^{\prime \prime} \mathrm{E}$, Stupskregion, Pomeranian Voivodship, northern Poland, Fig. 1) were used in our study. All horses participated in recreational horseback riding and were subjected to the resembling type of management. Horses were housed in individual boxes under natural spring photoperiod (sunrise at 06:00 h, sunset at 19:00 h), with feeding (hay and oat) provided twice a day, at 08.00 and $18.00 \mathrm{~h}$, and water available ad libitum. All horses were thoroughly examined clinically and screened for hematological, biochemical, and vital parameters, which were within reference ranges. The females were non-pregnant.

Training. Training started at 10:00 AM, lasted 1 hour, and included a ride of cross country by walking (10 min), trotting (15 min), walking (10 min), galloping $(15 \mathrm{~min})$, and walking $(10 \mathrm{~min})$. Environmental conditions during the ride had ranged from 18 to $23{ }^{\circ} \mathrm{C}$.

Blood samples. Blood was drawn from jugular veins of the animals in the morning, 90 minutes after feeding, while the horses were in the stables (between 8:30 and 10 AM), and immediately after the exercise session (between 11:00 AM and 2:00 PM). Blood was stored into tubes with $\mathrm{K}_{3}$-EDTA and held on ice until centrifugation at $3,000 \mathrm{~g}$ for 15 minutes. The plasma was removed. The erythrocyte suspension (one vol- 
ume) was washed with five volumes of saline solution three times and centrifuged at $3,000 \mathrm{~g}$ for 15 minutes. Plasma aliquots were frozen and stored at $-25^{\circ} \mathrm{C}$ until analyzed. Erythrocyte suspensions were used for the determination of the level of 2-thiobarbituric acid reacting substances (TBARS), carbonyl derivatives of protein oxidative modification, total antioxidant capacity (TAC), as well as for acid-induced erythrocyte hemolysis assay.

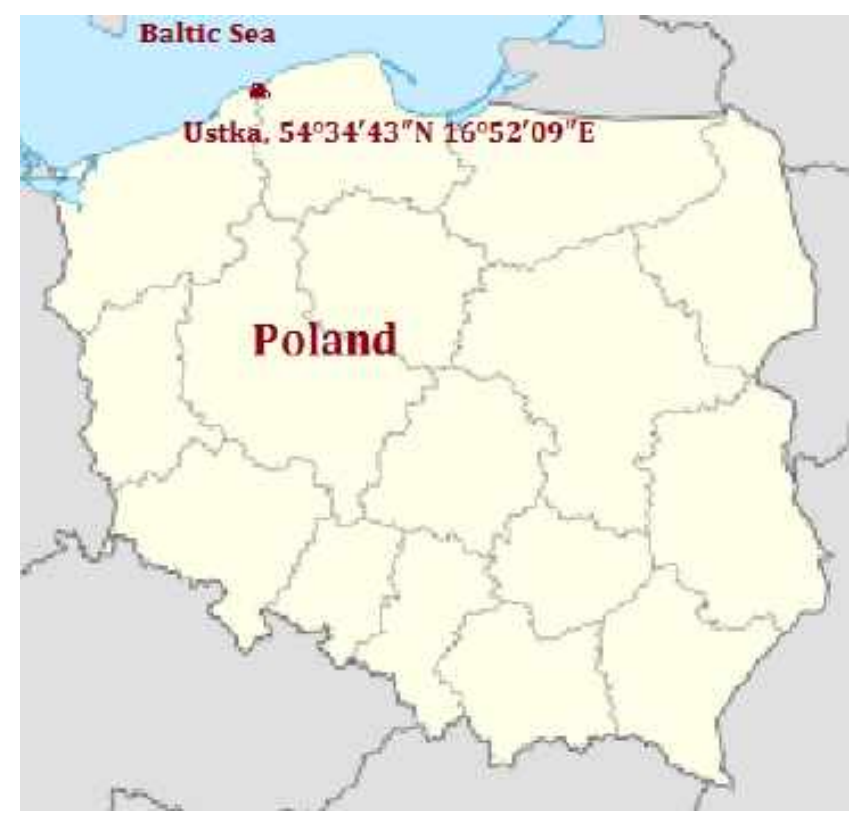

Fig. 1. Map of Poland with marked Ustka city $\left(54^{\circ} 34^{\prime} 43^{\prime \prime} \mathrm{N}\right.$ $\left.16^{\circ} 52^{\prime} 09^{\prime \prime} \mathrm{E}\right)$, where blood samples of horses were collected, Pomeranian Voivodship, northern Poland.

2-Thiobarbituric acid reactive substances (TBARS) assay. The lipid peroxidation was determined by quantifying the concentration of 2-thiobarbituric acid reacting substances (TBARS) for determining the malondialdehyde (MDA) concentration by the Kamyshnikov (2004). This method is based on the reaction of the degradation of lipid peroxidation product, MDA, with 2-thiobarbituric acid (TBA) under high temperature and acidity to generate a colored adduct that is measured spectrophotometrically. The $\mu \mathrm{mol}$ of MDA per $1 \mathrm{~L}$ was calculated by using $1.56 \cdot 10^{5} \mathrm{mM}^{-1} \cdot \mathrm{cm}^{-1}$ as the extinction coefficient.

The carbonyl derivative contents of oxidative modification of proteins (OMP) assay. The rate of protein oxidative destruction was estimated from the reaction of the resultant carbonyl derivatives of amino acid reaction with 2,4-dinitrophenyl hydrazine (DNFH) as described by Levine and co-workers (1990) and as modified by Dubinina and co-workers (1995). DNPH was used for determining carbonyl content in soluble and insoluble proteins. The carbonyl contents were calculated from the absorbance measurement at $370 \mathrm{~nm}$ and $430 \mathrm{~nm}$, and an absorption coefficient $22,000 \mathrm{M}^{-1} \cdot \mathrm{cm}^{-1}$. Carbonyl groups were determined spectrophotometrically from the difference in absorbance at $370 \mathrm{~nm}$ (aldehydic derivatives, $\mathrm{OMP}_{370}$ ) and $430 \mathrm{~nm}$ (ketonic derivatives, $\left.\mathrm{OMP}_{430}\right)$ and defined as $1 \mathrm{nmol}$ per $\mathrm{mL}$ of blood.

Total antioxidant capacity (TAC) assay. The TAC level in the erythrocytes was estimated by measuring the TBARS level following Tween-80 oxidation by Galaktionova et al. (1998). Plasma inhibits the $\mathrm{Fe}^{2+}$ /ascorbate-induced oxidation of Tween 80, resulting in a decrease in the TBARS level. The absorbance of the obtained solution was measured at $532 \mathrm{~nm}$. The absorbance of the blank was defined as $100 \%$. The level of TAC in the sample (\%) was calculated concerning the absorbance of the blank. 
Assay of Osmotic-induced Hemolysis of Erythrocytes. The osmotic resistance of erythrocytes in solutions with different $\mathrm{NaCl}$ concentrations was measured spectrophotometrically at the wavelength of $540 \mathrm{~nm}$ as described by Mariańska et al. (2003). The method is based on the determination of differences between osmotic resistance of erythrocytes to a mixture containing different concentration of sodium chloride $(0.1 \%$, $0.2 \%, 0.3 \%, 0.4 \%, 0.5 \%, 0.6 \%, 0.7 \%, 0.8 \%, 0.9 \%)$. The absorbance of the mixture contained erythrocytes and distilled water was determined as $100 \%$ hemolysis (blank). The degree of hemolysis in every test tube $(\%)$ was calculated by the absorbance of the blank. Hemolysis of erythrocytes (\%) in every test tube with different sodium chloride concentrations was expressed as a curve [12].

Statistical analysis. Results are expressed as mean \pm S.E.M. All variables were tested for normal distribution using the Kolmogorov-Smirnov test ( $p>0.05)$. To find significant differences (significance level, $\mathrm{p} \leq 0.05$ ) between at the rest and after training, the Wilcoxon signed-rank test was applied to the data. All statistical analyses were performed using STATISTICA 8.0 software (StatSoft, Krakow, Poland).

Results and discussion. Lipid peroxidation is a complex phenomenon involving the generation of many products [5]. Aldehydes, especially MDA, frequently used as markers of oxidative stress in response to exercise [19], can be measured by spectrophotometric or spectrofluorescentic assay. The most common method used to assess the MDA level during exercise training is the 2-thiobarbituric acid reactive substances (TBARS) assay. The marker of lipid peroxidation during the training session was measured through analysis of the TBARS level and shown in Fig. 2.

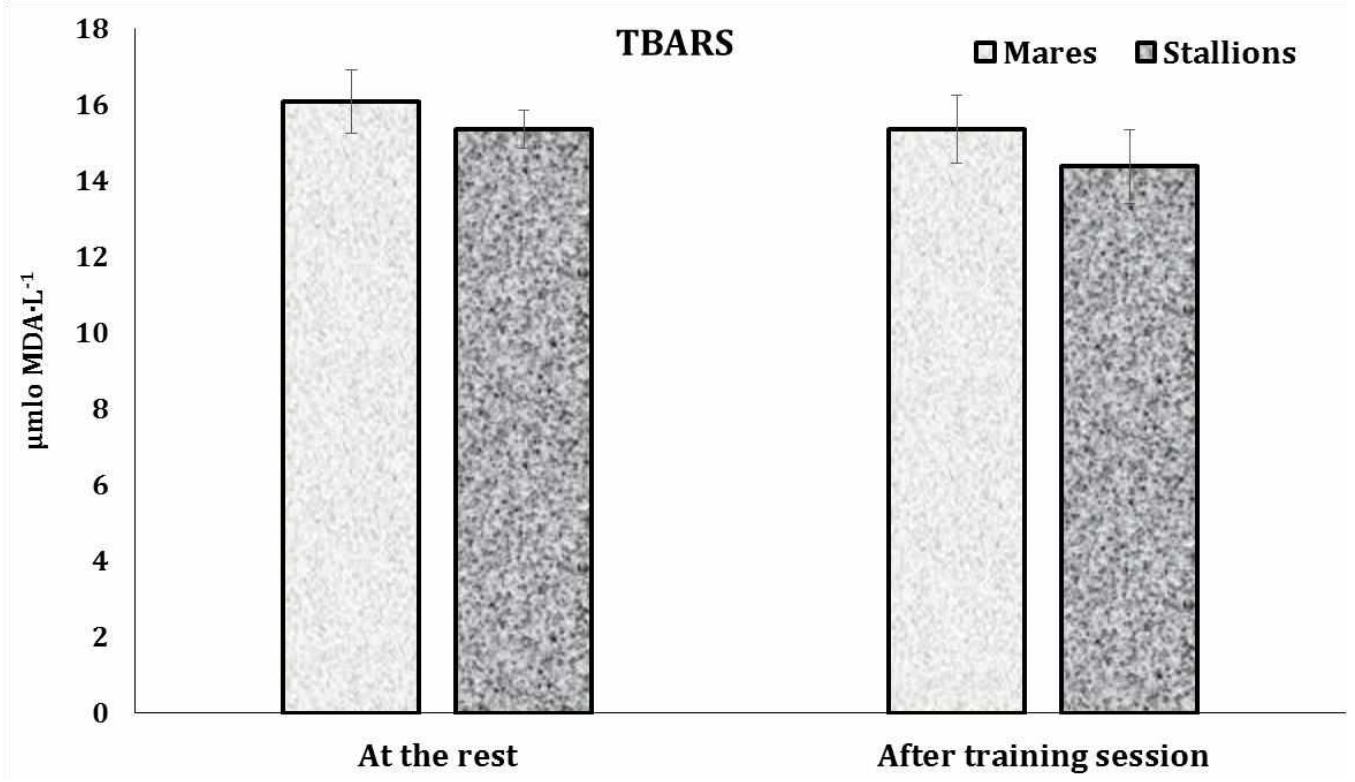

Fig. 2. The level of lipid peroxidation determined by quantifying of 2thiobarbituric acid reactive substrates (TBARS) level $\left(\mu \mathrm{mol} M D A \cdot L^{-1}\right)$ in the erythrocytes of ponies involved in recreational horseback ridings at the rest and after a training session. Values expressed as mean \pm S.E.M.

TBARS level in the erythrocytes of mares exhibited a non-significant decrease (by $1.8 \%, \mathrm{p}>0.05$ ) immediately after exercise as compared to the resting period. Also, the TBARS level in the erythrocytes of stallions was non-significantly decreased by $6.38 \%(\mathrm{p}>0.05)$ after the training sessions. There were no significant differences in the erythrocytes TBARS level between the resting period and after exercise both mares and stallions. Both at the rest and after the training session, the TBARS level in the 
erythrocyte suspensions of mares was non-significantly higher by $4.5 \%(\mathrm{p}>0.05)$ and by $8.9 \%$ (p>0.05) compared to stallions (Fig. 2).

The effect of a training session on carbonyl contents in the erythrocyte suspensions of mares and stallions of ponies are shown in Fig. 3. There were no statistically significant changes in the carbonyl derivatives of protein destruction in the erythrocytes of horses during training sessions. Decreased level of aldehydic (by $6.3 \%$ and $9.3 \%$, $\mathrm{p}>0.05$, respectively) and ketonic derivatives (by $25.5 \%$ and $8.1 \%, \mathrm{p}>0.05$, respectively) in the erythrocytes of mares and stallions after training sessions compared to the resting period was observed (Fig. 3).

Similarly to the TBARS level, at the rest period, significantly higher levels of aldehydic and ketonic derivatives were observed in the erythrocytes of mares (by $39.6 \%$ and $3.4 \%, \mathrm{p}>0.05)$ compared to the stallions. In a like manner, differences of aldehydic and ketonic derivatives of oxidatively modified proteins between mares and stallions after training sessions were noted, i.e. levels of aldehydic derivatives were higher in the mares by $41.6 \%$ ( $>0.05$ ) compared to the stallions, while ketonic derivatives were higher in the stallions by $16 \%$ ( $p>0.05$ ) compared to the mares (Fig. 3).

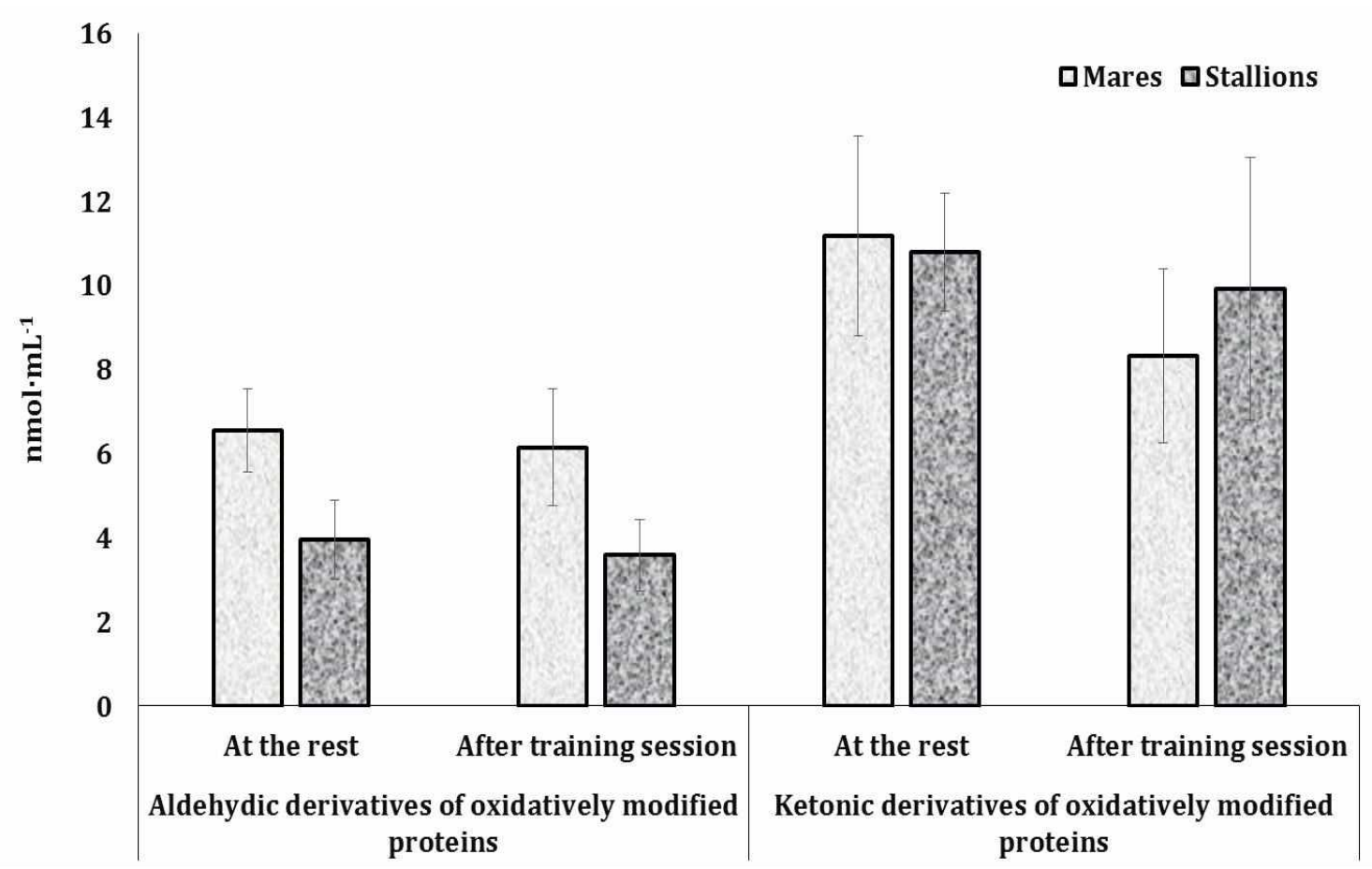

Fig.3. The aldehydic (A) and ketonic derivatives (B) of oxidatively modified proteins in the erythrocytes of ponies involved in recreational horseback ridings at the rest and after a training session. Values expressed as mean \pm S.E.M.

It is well known that total antioxidant capacity (TAC) includes enzymatic antioxidant such as superoxide dismutase, catalase, glutathione peroxidase, as well as some macromolecules (albumin, ceruloplasmin, urea, glutathione, ferritin, etc.), and its assessment may contain more information than a single review of its constituent parts [24]. The total antioxidant capacity (TAC) in erythrocyte suspensions is shown in Fig. 4.

TAC level in the erythrocytes of mares exhibited a non-significant increase (by $4.8 \%, \mathrm{p}>0.05)$ immediately after exercise as compared to the resting period. On the other hand, the TAC level in the erythrocytes of stallions was non-significantly decreased by $2.9 \%(\mathrm{p}>0.05)$ after the training sessions. There were no significant differ- 
ences in the erythrocytes TAC level between the resting period and after exercise both mares and stallions. Both at the rest and after the training session, the TAC level in the erythrocyte suspensions of stallions was non-significantly higher by $12.8 \%$ (p>0.05) and by $4.5 \%$ ( $\mathrm{p}>0.05)$ compared to mares (Fig. 4).

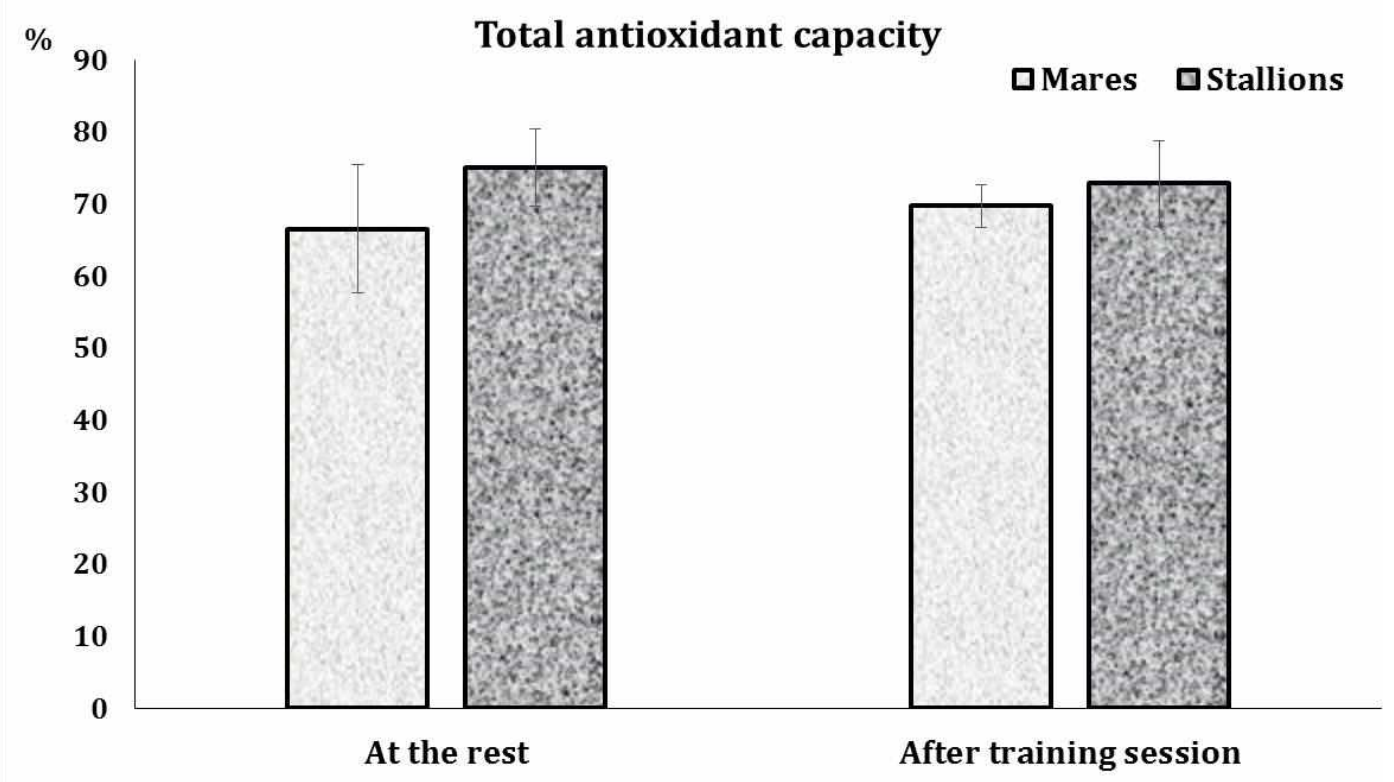

Fig. 4. The total antioxidant capacity (TAC) in the erythrocytes of mares and stallions of ponies involved in recreational horseback ridings at the rest and after a training session. Values expressed as mean \pm S.E.M.

Erythrocytes are the best indicators of increased generation of ROS and activation of oxidative stress. Therefore, the next goal of our study was the measurement of erythrocyte resistance to the hemolytic reagent (solutions with different concentrations of sodium chloride and urea) of the mares and stallions at the resting period and after exercise (Fig. 5).There were no significant differences in the percentage of hemolyzed erythrocytes between resting period and after training (incubation with $0.1 \%-0.9 \%$ $\mathrm{NaCl}$ and $0.12-0.15 \mathrm{~mol} / \mathrm{l}$ of urea) in the mares and stallions of ponies (Fig. 5). Among mares, decreased of erythrocyte hemolysis was observed after training session compared to the rest period (by $5.18 \%, 3.26 \%, 8.67 \%, 5.58 \%, 5.89 \%, 29.9 \%$, and $16.5 \%, \mathrm{p}>0.05$ after incubation with $0.3 \%-0.9 \% \mathrm{NaCl}$, respectively). Among stallions, similar to the data in mares, decreased of erythrocyte hemolysis was observed after training session compared to the rest period (by $3.9 \%, 2.1 \%, 1.49 \%, 10.7 \%, 15.74 \%$, $5.1 \%, 3.1 \%, 42.7 \%$, and $28.8 \%$, p>0.05 after incubation with $0.1 \%-0.9 \% \mathrm{NaCl}, \mathrm{re}-$ spectively) (Fig. 5).

Comparison of erythrocyte hemolysis in mares and stallions at the rest period showed increased values of hemolysis in the stallions (by $5.2 \%, 3.6 \%, 13.3 \%$, and $19.5 \%$ at incubation with $0.4 \%, 0.5 \%, 0.8 \%$, and $0.9 \%$, respectively). After the training session, decreased hemolysis was observed in the stallions compared to mares (by $5.81 \%, 5 \%, 2.87 \%, 4.39 \%, 3.65 \%, 6.1 \%$, and $7.3 \%$ at incubation with $0.1 \%, 0.2 \%$, $0.4 \%, 0.5 \%, 0.6 \%, 0.7 \%$, and $0.8 \%$, respectively) (Fig. 5). 


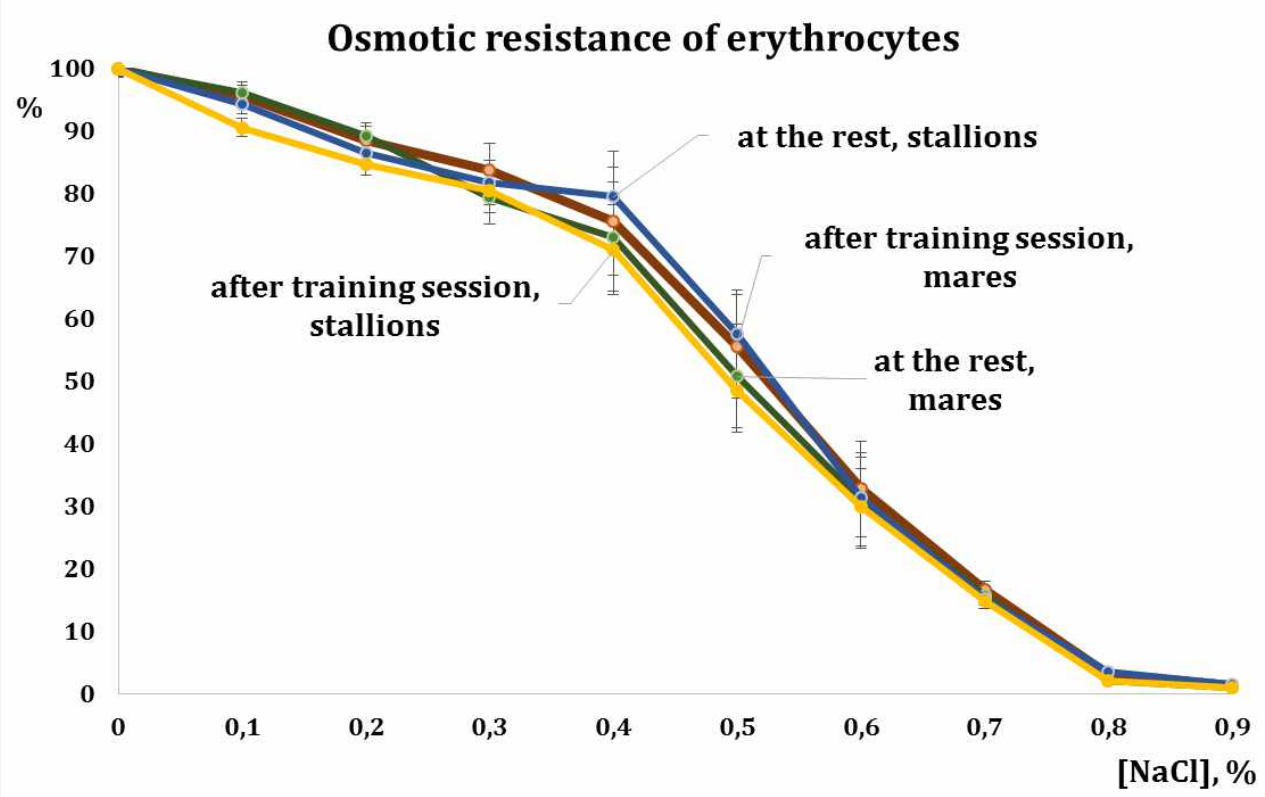

Fig. 5. Osmotic resistance of erythrocytes, measured by hemolysis of erythrocytes incubating in the solution with different concentrations of saline, in mares and stallions of ponies involved in recreational horseback ridings at the rest and after a training session. Values expressed as mean \pm S.E.M.

\section{Conclusions:}

1. Marker of lipid peroxidation (TBARS level) in the erythrocytes of both mares and stallions exhibited a non-significant decrease immediately after exercise as compared to the resting period. There were no significant differences in the erythrocytes TBARS level between the resting period and after exercise both mares and stallions. Both at the rest and after the training session, the TBARS level in the erythrocyte suspensions of mares was non-significantly higher compared to stallions.

2. Non-statistically decrease in levels of aldehydic and ketonic derivatives in the erythrocytes of mares and stallions after training sessions compared to the resting period was observed. Similarly to the TBARS level, at the rest period, significantly higher levels of aldehydic and ketonic derivatives were observed in the erythrocytes of mares compared to the stallions. In a like manner, differences of aldehydic and ketonic derivatives of oxidatively modified proteins between mares and stallions after training sessions were noted, i.e. levels of aldehydic derivatives were higher in the mares by $41.6 \%$ ( $>0.05$ ) compared to the stallions, while ketonic derivatives were higher in the stallions by $16 \%$ ( $\mathrm{p}>0.05)$ compared to the mares.

3. Total antioxidant capacity (TAC) level in the erythrocytes of mares exhibited a non-significant increase immediately after exercise as compared to the resting period. On the other hand, the TAC level in the erythrocytes of stallions was non-significantly decreased after the training sessions. There were no significant differences in the erythrocytes TAC level between the resting period and after exercise both mares and stallions. Both at the rest and after the training session, the TAC level in the erythrocyte suspensions of stallions was non-significantly higher compared to mares.

4. Among both mares and stallions, a non-significantly decreased erythrocyte hemolysis was observed after training sessions compared to the rest period. A comparison of erythrocyte hemolysis in mares and stallions at the rest period showed increased values of hemolysis in the stallions. After the training session, decreased hemolysis was observed in the stallions compared to mares. 
Efforts should be directed toward a thorough characterization of antioxidant defenses, as well as the correlation links between oxidative stress biomarkers and antioxidant defenses including age- and gender-related differences in the training programs of horses involved in the recreational horseback ridings.

\section{References}

1. Andriichuk, A., \& Tkachenko, H. (2017). Effect of gender and exercise on haematological and biochemical parameters in Holsteiner horses. J. Anim. Physiol. Anim. Nutr. (Berl)., 101(5), e404-e413.

2. Andriichuk, A., \& Tkachenko, H. (2015). Seasonal variations of hematological indices in equines involved in recreational horse riding. Journal of Ecology and Protection of the Coastline (Baltic Coastal Zone), 19, 11-22.

3. Andriichuk, A., \& Tkachenko, H., Kurhaluk, N. (2014). Gender differences of oxidative stress biomarkers and erythrocyte damage in well-trained horses during exercises. Journal of Equine Veterinary Science, 34, 978-985.

4. Andriichuk, A., Tkachenko, H., Kurhaluk, N., \& Tkachova, I. (2013). Oxidative stress biomarkers and erythrocyte hemolysis in trained Ukrainian warmblood horses under the influence of exercises. The AnimalBiology, 15(4), 9-24.

5. Chiaradia, E., Avellini, L., Rueca, F., Spaterna, A., Porciello, F., Antonioni, M.T., \& Gaiti, A. (1998).Physical exercise, oxidative stress and muscle damage in racehorses. Comp. Biochem Physiol. B Biochem. Mol. Biol., 119(4), 833-836.

6. ÇimenBurak, M. Y. (2008). Free radical metabolism in human erythrocytes. ClinicaChemicaActa, 390, 1-11.

7. Deaton, C. M., \& Marlin, D. J. (2003). Exercise-associated oxidative stress. Clinical Techniques in Equine Practice, 2, 278-291.

8. Fazio, F., Assenza, A., Tosto, F., Casella, S., Piccione, G., \& Caola, G. (2011). Training and haematochemical profile in Thoroughbreds and Standardbreds: A longitudinal study. Livestock Science, 141, 221-226.

9. Hinchcliff, K. W., \& Geor, R. J. (2008). The horse as an athlete: a physiological overview. In: Equine Exercise Physiology. The Science of Exercise in the Athletic Horse. Eds. K. W. Hinchcliff, R. J. Geor, A. J. Kaneps. Elsevier, 2-11.

10. Horohov, D. W., Sinatra, S. T., Chopra, R. K., Jankowitz, S., Betancourt, A., \& Bloomer, R. J. (2012). The effect of exercise and nutritional supplementation on proinflammatory cytokine expression in young racehorses during training. Journal of Equine Veterinary Science, 32, 805-815.

11.Kirschvink, N., de Moffarts, B., \& Lekeux, P. (2008). The oxidant/antioxidant equilibrium in horses. Vet. J., 177(2), 178-191.

12. Mariańska, B., Fabijańska-Mitek, J., \& Windyga, J. (2003). Laboratory studies in hematology. Textbook for Medical Students, PZWL, Warsaw [in Polish].

13. Nikolaidis, M. G., \& Jamurtas, A. Z. (2009). Blood as a reactive species generator and redox status regulator during exercise. Archives of Biochemistry and Biophysics, 490, 77-84.

14. Petibois, C., \& Déléris, G. (2005). Erythrocyte adaptation to oxidative stress in endurance training. Archives of Medical Research, 36, 524-531.

15. Piccione, G., Casella, S., Giannetto, C., Messina, V., Monteverde, V., Caola, G., \& Guttadauro, S. (2010). Haematological and haematochemical responses to training and competition in Standardbred horses. Comp. Clin. Pathol., 19, 95-101.

16. Radák, Z., Sasvári, M., Nyakas, C., Taylor, A.W., Ohno, H., Nakamotoo, H., $\&$ Goto, S. (2000). Regular training modulates the accumulation of reactive carbonyl 
derivatives in mitochondrial and cytosolic fractions of rat skeletal muscle. Arch. Bioch. Biophys., 383, 114-118.

17. Radák, Z., Zhao, Z., Koltai, E., Ohno, H., \& Atalay, M. (2013). Oxygen consumption and usage during physical exercise: the balance between oxidative stress and ROS-depend adaptive signaling. Antioxid. Redox Signal., 18(10), 1208-1246.

18. Tkachenko, H., Pażontka-Lipiński, P., \& Witaszek, P. (2016). Seasonal alterations in exercise-induced oxidative stress of horses involved in recreational horseback ride. Globalisation and regional environment protection. Technique, technology, ecology. Eds T. Noch, W.Mikołajczewska, A.Wesołowska. Gdańsk, Gdańsk High School Publ.,193-212.

19. Urso, M. L., \& Clarkson, P. M. (2003). Oxidative stress, exercise, and antioxidant supplementation. Toxicology, 189, 41-54.

20. Watson, T. A., MacDonald-Wicks, L. K., \& Garg, M. L. (2005). Oxidative stress and antioxidant in athletes undertaking regular exercise training. International Journal of Sport Nutrition and Exercise Metabolism, 15, 131-146.

\section{ВЫЗВАННЫЕ ФИЗИЧЕСКИМ ТРЕНИНГОМ ИЗМЕНЕНИЯ $В$ СОДЕРЖАНИИ БИОМАРКЕРОВ ОКИСЛИТЕЛЬНОГО СТРЕССА ЭРИТРОЦИТОВ У ПОНИ, УЧАСТВУЮЩИХ В РЕКРЕАЦИОННОЙ ВЕРХОВОЙ ЕЗДЕ}

Ткаченко Г., Кургалюк Н., Институт биологии и наук о Земле Поморской академии в Слупске, Польша

Ткачова И., Институт животноводства, Начиональная академия аграрных наук Украинь

Целью исследования был анализ биомаркеров окислительного стресса, а также устойчивости эритроцитов у кобыл и жеребцуов пони, участвующих в рекреационной верховой езде. В нашем исследовании были использованы десять здоровых взрослых пони (5 жеребцов и 5 кобыл), в возрасте 5-11 лет, из Поморских регионов Польши (Устка, Поморское воеводство, Польша). Все ломади участвовали в рекреачионной езде. Тренировка продолжалась 1 час и включала выездку по пересеченной местности с ходьбой (10 минут), рысь (15 минут), ходьбу (10 минут), галоп (15 минут) и ходьбу (10 минут). Кровь отбирали из яремных вен животных утром, через 90 минут после кормления и сразу после тренировки. Маркер перекисного окисления липидов (вещества, реагирующие с 2тиобарбитуровой кислотой, TBARS), альдегидные и кетоновые производные окислительно модифицированных белков, уровень общей антиоксидантной активности (ТАC) в эритрочитах как кобыл, так и жеребцов, показали незначительные изменения сразу после физической нагрузки по сравнению с периодом отдыха. Как в покое, так и после тренировки уровни TBARS, альдегидных и кетоновых производных в эритрочитарных суспензиях кобыл были незначительно выше по сравнению с жеребиами. Аналогичным образом были отмечены различия в уровнях альдегидных и кетоновых производных окислительно модифицированных белков между кобылами и жеребцами после тренировок. Как в покое, так и после тренировки уровень ТАС в эритрочитарных суспензиях жеребцов был незначительно выше по сравнению с кобылами. Как у кобыл, так и у жеребиов, после тренировок наблюдалось незначительное снижение гемолиза эритрочитов по сравнению с периодом отдыха. Сравнение гемолиза эритроцитов в период отдыха показало увеличение значений гемолиза у жеребцов. После тренировки наблюдалось снижение гемолиза у жеребиов по сравнению с кобылами. Усилия должны быть направлены на тщчательную характеристику антиоксидантной защчтты, а 
также корреляциионных связей между биомаркерами окислительного стресса и антиоксидантной защиты, включая возрастные и гендерные различия в программах тренировок лошадей, участвуюших в рекреаџионной верховой езде.

Ключевые слова: вещества реагирующие с 2-тиобарбитуровой кислотой (ТБК-активные продукты), альдегидные и кетоновые производные, окислительно-модифицированные белки, общая антиоксидантная способность, гемолиз эритрочитов, тренинг.

ВИКЛИКАНІ ФІЗИЧНИМ ТРЕНІНГОМ ЗМІНИ РІВНЯ БІОМАРКЕРІВ ОКИСНЮВАЛЬНОГО СТРЕСУ ЕРИТРОЦИТІВ У ПОНІ, ЩО БЕРУТЬ УЧАСТЬ У РЕКРЕАЦІЙНІЙ ВЕРХОВІЙ ЇЗДІ

Ткаченко Г., Кургалюк Н., Інститут біологї̈ та наук про Землю, Поморська Академія в Слупську, Польщза

Ткачова І., Інститут твариннищтва Національної академї аграрних наук України

Метою дослідження був аналіз біомаркерів окиснювального стресу, а також стійкості еритроцитів у кобил і жеребців поні, щио беруть участь у рекреаиіииній верховій їзді. У нашому дослідженні були використані десять здорових дорослих поні (5 жеребиів і 5 кобил), у віщі 5-11 років, з Поморських регіонів Польщзі (Устка, Поморське воєводство, Польща). Всі коні брали участь у рекреаційній їзді. Тренування тривало 1 годину і включало поӥздку по пересіченій місиевості 3 ходьбою (10 хвилин), риссю (15 хвилин), ходьбою (10 хвилин), галопом (15 хвилин) $i$ ходьбою (10 хвилин). Кров відбирали з яремних вен тварин враниі, через 90 хвилин після годування і відразу після тренування. Маркери перекисного окиснення ліпідів (речовини, щьо реагують з 2-тіобарбітурової кислотою, TBARS), альдегідні $і$ кетонові похідні окиснювально модифікованих білків, рівень загальної антиоксидантної активності (ТАС) в еритроцитах як кобил, так $і$ жеребців, показали незначні зміни відразу після фізичного навантаження в порівнянні з періодом відпочинку. Як в спокої, так і після тренування рівні TBARS, альдегідних і кетонових похідних в еритрочитарних суспензіях кобил були незначно вищі в порівнянні з жеребцями. Аналогічним чином були відзначені відмінності в рівнях альдегідних $i$ кетонових похідних окиснювально модифікованих білків між кобилами і жеребцями після тренувань. Як в спокої, так і після тренування рівень ТАС в еритроцитарних суспензіях жеребиів був незначно вищий в порівнянні з кобилами. Як у кобил, так $і$ у жеребиів, після тренувань спостерігалося незначне зниження гемолізу еритроцитів у порівнянні з періодом відпочинку. Порівняння гемолізу еритроциитів в період відпочинку показало вищі значення гемолізу у жеребиів. Після тренування спостерігалося зниження гемолізу у жеребців в порівнянні з кобилами. Зусилля мають бути спрямовані на ретельну характеристику антиоксидантного захисту, а також корелячійних зв'язків між біомаркерами окиснювального стресу $і$ антиоксидантного захисту, включаючи вікові $і$ гендерні відмінності в програмах тренувань коней, щуо беруть участь у рекреачійній верховій їзді.

Ключові слова: речовини реагуючі з 2-тіобарбітурової кислотою (ТБКактивні продукти), альдегідні і кетонові похідні, окиснювально-модифіковані біл$\kappa и$, загальна антиоксидантна активність, гемоліз еритроцитів, тренінг. 